\title{
Using a field radiometer to estimate instantaneous sky clearness
}

\author{
Eduardo G. Souza ${ }^{1}$, Peter Scharf ${ }^{2}$, Ken A. Sudduth ${ }^{3} \&$ James. D. Hipple ${ }^{2}$
}

\begin{abstract}
Reflectance measurements of crop plants and canopies show promise for guiding within-season, variable-rate nitrogen (N) application. Most research results have been obtained around solar noon with clear skies. However, for practical application, the system must work under cloudy skies or away from solar noon. The objective of this work was to assess the effect of cloud conditions on reflectance measurements of a corn canopy. The approach was to estimate an instantaneous sky clearness index $(\mathrm{ICl})$ which could be used to correct field radiometer data for variations in cloud cover, such that the same reflectance reading would be obtained (and the same $\mathrm{N}$ recommendation made) for the same plants regardless of cloud conditions. Readings were taken from morning until night over 11 days with a range of sky conditions (sunny, overcast, partly cloudy). Data from clear days were used to estimate the theoretical expected spectral global radiation incident on a horizontal surface. The $\mathrm{ICl}$ was calculated as the ratio between the actual spectral global radiation and the corresponding theoretical global radiation. Analysis of the $\mathrm{ICl}$ for each band showed that the influence of cloudiness was different for each band. Thus, the cloud effect could not be compensated by the use of a band ratio or vegetation index.
\end{abstract}

Key words: precision agriculture, nitrogen management, reflectance, cloud

\section{Radiômetro de campo para cálculo da clareza instantânea do céu}

\section{RESUMO}

Medidas da reflectância das folhas das plantas mostram-se promissoras para a aplicação de nitrogênio a taxa variável; entretanto, a maioria dos resultados de pesquisa foi obtida ao redor do meio-dia solar e com céu aberto, porém para aplicações práticas um sistema tem que trabalhar debaixo de céu nublado e fora do meio-dia solar. O objetivo deste trabalho foi avaliar o efeito de condições de nuvem em medidas de reflectância de milho. A abordagem foi calcular um índice instantâneo de clareza do céu $(\mathrm{ICl})$ que pode ser usado para corrigir dados de radiômetros de campo para variações em cobertura de nuvem, tal que essas reflectâncias seriam obtidas (e a mesma recomendação de $\mathrm{N}$ seria feita) para as mesmas plantas, não importando as condições de nebulosidade. Usaram-se leituras de manhã até a noite, de 11 dias, perfazendo uma gama variada de condições de céu (ensolarado, nublado e parcialmente nublado). Os dados de dias claros serviram para se calcular a irradiação global espectral teórica esperada em uma superfície horizontal. O ICI foi calculado como a relação entre a radiação global espectral real e a radiação global teórica correspondente. A análise do $\mathrm{ICl}$ para cada uma das bandas mostrou que a influência da nebulosidade foi diferente para cada banda e, portanto o efeito das condições de nuvem não poderia ser compensado pelo uso de uma relação entre reflectâncias de diferentes bandas ou pelo uso de índices de vegetação.

Palavras-chave: agricultura de precisão, manejo de nitrogênio, reflectância, nuvem

${ }^{1}$ CCET/UNIOESTE, Grupo de Pesquisa GROSAP, Bolsista do CNPq, CEP 85814-110, Cascavel, PR. CP 711. Fone (45) 3220 3199. Email: godoy@unioeste.br

2 University of Missouri, Columbia, 214 E Waters Hall, Columbia, MO, EUA. Fone: 573-882-0777. Email: ScharfP@missouri.edu

${ }^{3}$ USDA-ARS, Columbia, 245 Agricultural Engineering Building, Columbia, MO, EUA. Fone: 573-882-4587. Email: SudduthK@missouri.edu 


\section{INTRODUCTION}

Much effort has been expended in the development of precision management systems for phosphorus (P) and potassium (K) fertilizers in row crop production. Similar development for nitrogen $(\mathrm{N})$ fertilizers has been hindered by the complex interactions in the soil-air-water matrix. While soil $\mathrm{P}$ and $\mathrm{K}$ levels are easily measured and mapped as a basis for variable-rate applications, relatively rapid $\mathrm{N}$ transformations seriously impair a soil-test-based approach to site-specific $\mathrm{N}$ management for both pre- and in-season applications. A sensorbased, real-time variable-rate application system for $\mathrm{N}$ fertilizer has the potential to reduce input costs, improve yields, and reduce $\mathrm{N}$ losses to the environment.

Traditionally, soil testing, plant tissue analysis, and longterm field trials have been used for assessing $\mathrm{N}$ availability for crops (Daughtry et al., 2000). Recently, chlorophyll meters have been used to monitor plant $\mathrm{N}$ status by measuring transmittance of radiation through a leaf in two wavelength bands centered near 650 and 940 nm (e.g., Peterson et al., 1993; Blackmer et al., 1994).

According to Tumbo et al. (2000) measurement of spectral reflectance is the most promising non-contact and nondestructive approach for on-the-go sensing of $\mathrm{N}$ deficiency in corn. They also suggested that $\mathrm{N}$ or chlorophyll responds well at $550 \mathrm{~nm}$, where the higher $\mathrm{N}$ application results in less reflected energy at $550 \mathrm{~nm}$. Previous research at University of Missouri has shown that corn reflectance of visible and near-infrared light, measured with a Cropscan radiometer, can be used to predict the amount of $\mathrm{N}$ fertilizer needed by the crop (Scharf \& Lory, 2000). However, the relationship between $\mathrm{N}$ level and reflectance may be affected by variable solar irradiance.

Tumbo et al. (2000) measured the spectral reflectance response patterns (SRRPs) of corn plants at the same chlorophyll level with different fractions of cloud cover and solar angles, as a function of the spectral irradiance patterns (SIPs). Data for different SIPs were measured to investigate the effect of cloud cover. It was seen that as the solar irradiance decreases, with increase in the cloud cover, the SIPs stay almost parallel to each other, but the SRRPs showed a different behavior. This observation implies that an irradiance value at one particular wavelength can be used for relative comparison of different SIPs. It was also reported that the percent reflectance did not remain constant for different irradiances.

According to Tumbo et al. (2000) the main problem in $\mathrm{N}$ stress detection using data collected under cloudy skies or away from solar noon is that the reflectance characteristics of canopies/plants under these conditions are not well known. Most research used data collected around solar noon and with clear skies. However, for practical application, a $\mathrm{N}$ application system must work under cloudy skies or away from solar noon.

Campbell \& Norman (1998) showed that the total radiation reaching the ground depends mainly on solar zenith and azimuth angles and cloud cover. They also stated that the presence of certain types of clouds, such as nimbostratus and fog, can attenuate as much as $80 \%$ of the total radiation.

The global (total horizontal) irradiance incident on a surface is the sum of the direct normal (beam) $\mathrm{I}_{\mathrm{b}}\left(\mathrm{W} \mathrm{m}^{-2}\right)$ and diffuse $\mathrm{I}_{\mathrm{d}}\left(\mathrm{W} \mathrm{m}^{-2}\right)$ components. According to Iqbal (1983), theoretical determination of direct and diffuse irradiances is quite difficult. Such a task requires data on type and optical properties of clouds, cloud amount, thickness, position, and the number of atmosphere layers. However, completely sunny and total cloudcover data are widely available.

On time-scales of a few minutes, the presence of scattered clouds, especially towering cumulus, can reflect additional solar radiation onto the pyranometer to cause irradiance measurements in excess of the corresponding extraterrestrial value (a physical limit) (Atmospheric Radiation Measurement, 2001).

According to Gao \& Li (2000) because of their partially transparent nature, thin cirrus clouds are difficult to detect in satellite images, particularly over land, both in the visible and in the 1,000-12,000 nm IR atmospheric window regions. Thin cirrus clouds introduce additional path-scatteredradiances to the 660 and $860 \mathrm{~nm}$ channels. As a result, NDVI values calculated from data with cirrus contamination are different from those computed from data without any cirrus contamination. These authors proposed an empirical technique developed to obtain unbiased estimates of NDVI values from remotely sensed data. The method uses scatter plots between the 1,380 nm cirrus detecting channel and another channel near 660 or $860 \mathrm{~nm}$ to estimate thin cirrus scattering effects. The results show the estimates of NDVI values can be improved quantitatively after the removal of thin cirrus scattering effects from remotely sensed data.

Because of the complex three-dimensional geometry of a plant canopy, light returned from the canopy is a complex mixture of multiply reflected and/or transmitted components (Analytical Spectral Devices, Inc., 2001). The canopy-level optical signal depends upon illumination and viewing geometry, canopy structure, leaf optical properties, and the optical properties of other vegetative and non-vegetative components within and below the canopy. There is a strong dependence on illumination and viewing geometry. Both the overall brightness of the canopy and the shape of the spectral signature (e.g. the red to infrared ratio) are dependent on the illumination and viewing geometry. Thus, it is only by controlling the viewing and illumination geometry that changes in canopy reflectance attributable to the canopy itself can be detected. Spectral Vegetation Indices (SVI) are useful to minimize variations due to extraneous factors and maximize sensitivity to the variable of interest, in this case the corn leaf chlorophyll concentration (Daughtry et al., 2000).

It is important to emphasize that there is much research investigating the influence of clouds in satellite imagery (Gao \& Li, 2000; Simpson et al., 2000) but few reports about the influence of clouds on remote sensing data acquired at the earth's surface.

The objective in this work was to estimate instantaneous sky clearness using a field radiometer to assess the effect of cloud conditions on reflectance measurements of a corn canopy. 


\section{MATERIAL AND METHODS}

\section{General procedures}

All measurements were made at the University of Missouri Agronomy Research Center, located at Lat. 38 ${ }^{\circ} 54^{\prime}$ and Long. $-92^{\circ} 12^{\prime}$. Data were taken from morning till night during the period of 06/13/2001 to 06/25/2001. An upwardlooking Crop Circle multispectral radiometer measured the actual spectral global irradiation incident on the horizontal plane. Spectral irradiance was evaluated in the 460, 550, 680 and $800 \mathrm{~nm}$ bands (10 $\mathrm{nm}$ bandwidth) by reading the digital counts of the multispectral radiometer. The respective counts from each band were called RupR460, RupR550, RupR680 and RupR800.

Similarly to the clearness index from Liu \& Jordan (1960) but as a function of time we defined the instantaneous clearness index (ICI) as the ratio between the actual spectral global radiation incident on a horizontal surface ( $\mathrm{I}, \mathrm{W} \mathrm{m} \mathrm{mm}^{-2}$ ), measured with the up-looking sensor of the radiometer, and the theoretical expected spectral global radiation incident on a horizontal surface $\left(\mathrm{I}_{0}, \mathrm{~W} \mathrm{~m}^{-2} \mathrm{~nm}^{-1}\right)$, modeled from results at the same locations using only clear days:

$$
\mathrm{ICI}=\frac{\mathrm{I}}{\mathrm{I}_{\mathrm{O}}}
$$

To build the model of the theoretical expected spectral global radiation incident on a horizontal surface $\left(\mathrm{I}_{0}\right)$ all cases with cloudy conditions were excluded from five selected days from the data base. Variables selected were: sun zenith angle $(\psi)$, time of day $(\mathrm{t}, \mathrm{h})$ and day of the year (DOY). To reduce expected multicollinarity the dependent variables were centered to centered sun angle $\psi_{\mathrm{C}}$, centered time of day $\mathrm{t}_{\mathrm{C}}$, and centered day of year doy $_{C}$ :

$$
\begin{gathered}
\Psi_{\mathrm{C}}=\Psi-45 \\
\mathrm{t}_{\mathrm{C}}=\mathrm{t}-13 \\
\mathrm{DOY}_{\mathrm{C}}=\mathrm{DOY}-170
\end{gathered}
$$

where the centered constants were chosen to provide symmetry to the data, e.g., 45 is half of the maximum possible $\psi, 13$ is the solar noon time (daylight saving time) during the data collection period, and 170 is the mid-point day of the data collection period.

\section{Statistical procedures}

The statistical analysis was carried out using a linear model that specifies the (linear) relationship between a dependent (or response) variable $\mathrm{Y}$, and a set of predictor variables, the $\mathrm{X}$ 's, so that:

$$
\mathrm{Y}=\mathrm{b}_{0}+\mathrm{b}_{1} \mathrm{X}_{1}+\mathrm{b}_{2} \mathrm{X}_{2}+\ldots+\mathrm{b}_{\mathrm{k}} \mathrm{X}_{\mathrm{k}}
$$

where $b_{0}$ is the regression coefficient for the intercept and the bi values are the regression coefficients (for variables 1 through $\mathrm{k}$ ) computed from the data.

In addition to fitting the whole model for the specified type of analysis, different methods for automatic model building were employed in the analyses. Specifically, forward stepwise, backward stepwise and best-subset search procedures were selected. A 0.05 p-value of the F distribution was selected to control entry and removal of effects from the model. The adjusted R-squared and the Mallow's Cp statistic were used to find the best models of all possible subsets of effects specified.

\section{RESULTS AND DISCUSSION}

Table 1 presents the best models for the theoretical expected spectral global radiation called expRup460, expRup550, expRup680 and expRup800 as a function of centered zenith sun angle $\mathrm{y}_{\mathrm{C}}$, centered time of day $\mathrm{t}_{\mathrm{C}}$, and centered day of year doy $_{C}$. As shown in Figure 1, the fit of the model to the data is very good in the clear part of the day with $\mathrm{R}^{2}$ greater than 0.97 for predicting observed radiation. This was expected, since the model accounts for all sources of variation in observed radiation with the exception of minor (non-cloud) atmospheric effects. The modeled radiation values could then be used to assess the effects of clouds on observed radiation.

To better understand the practical meaning of the instantaneous clearness index (ICI) three points were selected in Figure 1. The respective ICI were 1.0, 0.61 and 1.21 for the points A, B, and C. Point A represented clear sky while point $B$ represented clouds in the irradiation path, reducing observed radiation by about 39\% relative to the expected radiation. Point $\mathrm{C}$ represented a special situation where scattered clouds reflected additional solar radiation onto the radiometer, causing a $21 \%$ increase in the observed radiation above the expected level (as cited by Atmospheric Radiation Measurement, 2001). All three

\begin{tabular}{|c|c|c|c|c|}
\hline & \multicolumn{4}{|c|}{ Band (nm) } \\
\hline & expRup460 & expRup550 & expRup680 & expRup800 \\
\hline Intercept & -3036.921 & 9106.391 & 5254.652 & 14348.377 \\
\hline $\operatorname{doy}_{c}$ & -303.644 & -29.169 & -257.974 & -122.476 \\
\hline $\operatorname{doy}_{c}^{2}$ & 9.832 & & 28.121 & -12.430 \\
\hline $\mathrm{t}_{\mathrm{c}}$ & -540.985 & 184.088 & -31.906 & \\
\hline $\mathrm{t}_{\mathrm{c}}^{2}$ & 1066.231 & -627.847 & & -398.941 \\
\hline $\mathrm{t}_{\mathrm{c}}{ }^{3}$ & 6.660 & & & 3.193 \\
\hline$t_{c}^{4}$ & & 1.441 & & \\
\hline $\mathrm{t}_{c^{5}}$ & & & -0.123 & \\
\hline$\psi_{C}$ & -782.489 & 309.557 & -115.725 & 99.126 \\
\hline$\psi c^{2}$ & -8.887 & 3.447 & -0.817 & 1.449 \\
\hline $\mathrm{R}^{2}$ & 0.977 & 0.973 & 0.979 & 0.985 \\
\hline
\end{tabular}
conditions are likely to occur in a regular day. If sunlight

Table 1. Regression coefficient estimates for the best models for the theoretical expected spectral global radiation (expRup460, expRup550, expRup680 and expRup800)

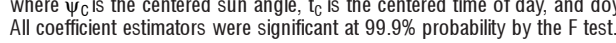




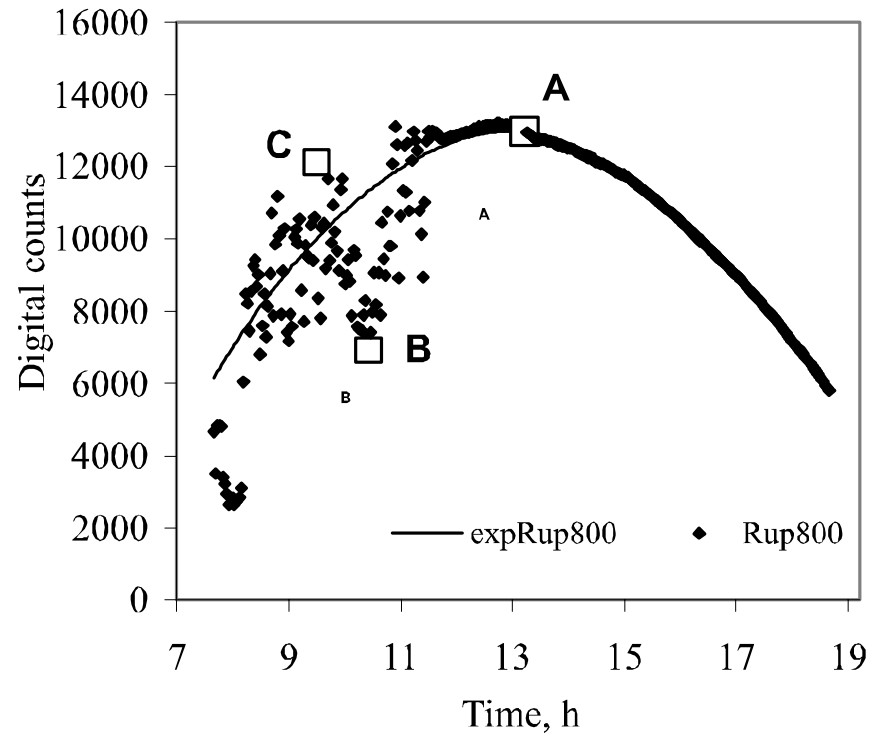

Figure 1. The actual spectral global radiation incident on a horizontal surface at band $800 \mathrm{~nm}$ (Rup800) and the respective theoretical expected radiation (expRup800) as a function of time of day at the University of Missouri Agronomy Research Center on 06/15/2001 (DOY =168)

reflectance measurements are to be used in agricultural applications, the effects of clouds on radiation reaching the earth's surface must be understood for different wavelengths.

Figure 2 presents the instantaneous clearness index (ICI) at 550, 680 and 800 nm (ICI_550, ICI_680 and ICI_800) as a function of time of day. It can be seen in the cloudy part of the day (morning until 11:30AM) that the influence of the cloud cover was different for each band. Because of this, these variations could not be compensated for by only using a band ratio or vegetation index. This is in accordance with Tumbo et al. (2000).

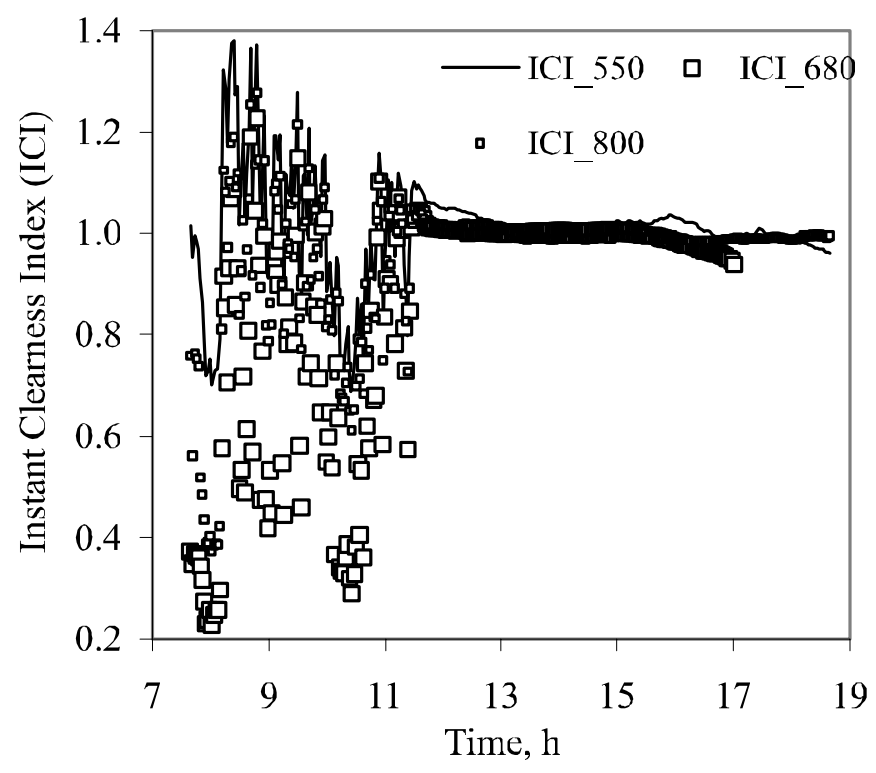

Figure 2. The instantaneous clearness index at 550,680 and $800 \mathrm{~nm}$ $(\mathrm{ICl} 550, \mathrm{ICl} 680$ and $\mathrm{ICl} 800)$ as a function of time of day at the University of M̄issouri Āgronomy Research Center on 06/15/2001 (DOY =168)
The behavior of different visible/near-infrared combinations is of particular interest in diagnosing nitrogen deficiency (Bausch \& Duke, 1996; Scharf \& Lory, 2000). This research examined two wavelength pairs, 550 and $800 \mathrm{~nm}$, and 680 and $800 \mathrm{~nm}$. Figure 3 shows the differences between ICI_550 and ICI_800 and between ICI_680 and ICI_800. The difference ICI_550 - ICI_800 was mostly positive meaning that the green band was increased more than near infrared by cloud reflection (Point $C$ in Figure 1) and decreased less than near infrared by cloud cover (Point $B$ in Figure 1). The opposite behavior was seen in the difference ICI_680 ICI_800, indicating that red light is more blocked by cloud cover and less reflected from cloud edges than near-infrared light. Also the difference ICI_550 - ICI_800 had a smoother behavior than the difference ICI_680 - ICI_800. This suggests more stable behavior of 550 and $800 \mathrm{~nm}$ combinations over a range of cloud conditions than combinations of 680 and 800 $\mathrm{nm}$. This observation may be in part responsible for or complementary to the observation of Gitelson et al. (1996) that NDVI calculated with green instead of red provided superior

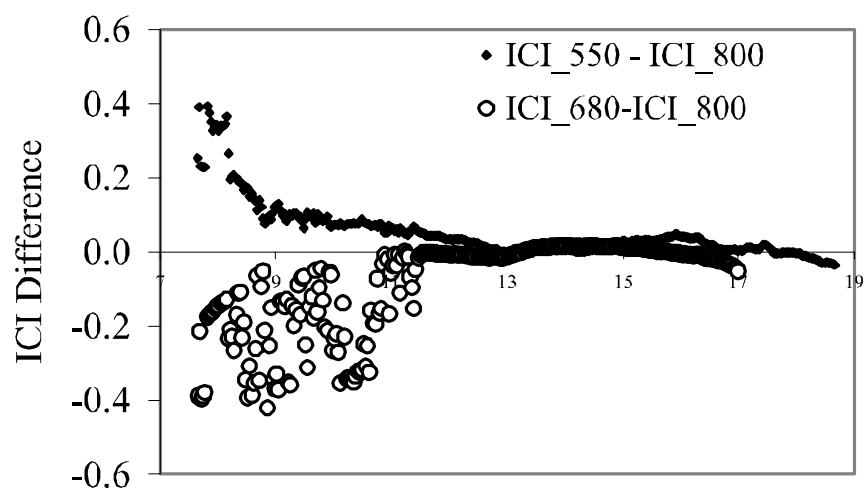

Time, $\mathrm{h}$

Figure 3. The difference between the instantaneous clearness index at 550 and $800 \mathrm{~nm}$ (ICl_550 minus ICl_800) and between ICI_680 and ICl_800 as function of time of day at the University of Missouri Agronomy Research Center (06/15/2001)

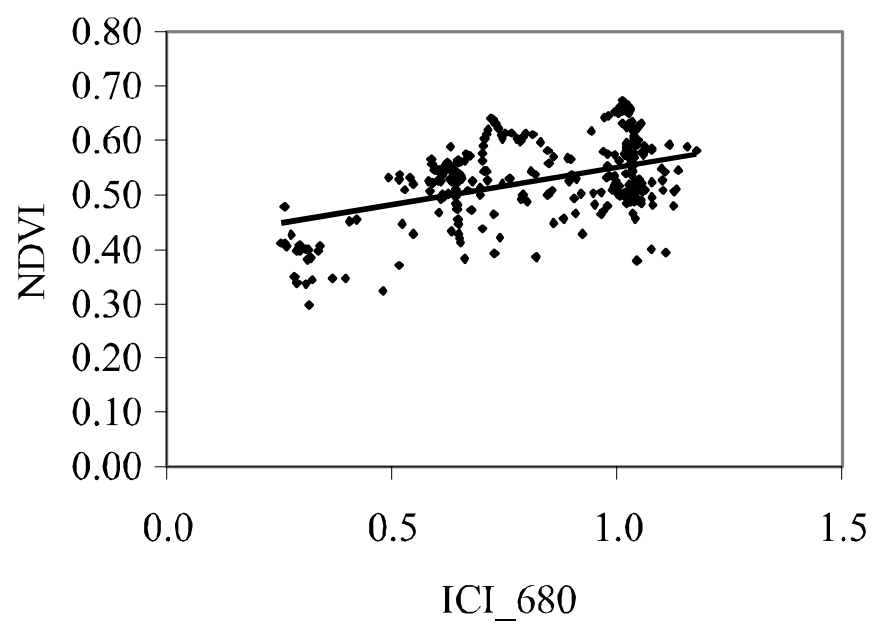

Figure 4. The NDVI vegetation index as a function of the instantaneous clearness index at $680 \mathrm{~nm}(\mathrm{ICl} 680)$ showing the dependence of the NDVI on the ICl_680 due to cloud cover on 06/17/2001 (DOY $=168)$ 
performance in some situations. All these results must be confirmed by further research.

One practical use for the ICI variable is to provide more stable and reliable estimates of vegetation reflectance measurements. Figure 4 shows the NDVI vegetation index as a function of the instantaneous clearness index for the 680 nm band (ICI_680) and its dependence on cloud cover conditions. In other words, the NDVI should be corrected for the influence of clouds, using a relationship such as that shown in Figure 4, before being used to estimate green biomass or end-of-season above-ground dry biomass. This conclusion is in accordance with Gao et al. (2000), who studied the influence of thin cirrus clouds on satellite-based estimates of NDVI. The results of this research also agree with those of Tumbo et al. (2000).

\section{CONCLUSIONS}

1. The model used to estimate theoretical expected spectral global radiation of a field radiometer showed a very good result as the fitting of the generated model to the actual data.

2. Analysis of the instantaneous clearness index ICI for the bands 460, 550, 680, and $800 \mathrm{~nm}$ showed that the influence of cloud cover was different for each band and could not be compensated by only using a band ratio or vegetation index.

\section{ACKNOWLEDGEMENTS}

The authors are grateful for the support provided by the University of Missouri, Columbia-MO, USA and the State University of Western Parana - Unioeste, Brazil. They are also grateful for the financial support provided by the National Council of Scientific and Technological Development - CNPq, Brazil. The authors are also thankful to Larry Mueller for help with field work.

\section{LITERATURE CITED}

Analytical Spectral Devices, Inc. Field spectrometry: Techniques and instrumentation. http://www.asdi.com/apps/remote sensing. html. 20 Nov. 2001.
Atmospheric Radiation Measurement, Pyranometer. http://www.arm.gov/ docs/instruments/static/pyra.html\#Description_of_Observational_ Specifications. 20 Nov. 2001.

Bausch, W. C.; Duke, H. R. Remote sensing of plant nitrogen status in corn. Transaction of the ASAE, St. Joseph, v.39, n.5, p.1869-1875, 1996.

Blackmer, T. M.; Schepers, J. S.; Varvel, G. E. Light reflectance compared with other nitrogen stress measurement in corn leaves. Agronomy Journal, Madison, v.86, n.6, p.934-938, 1994.

Campbell, G. S.; Norman, J. M. An introduction to environmental biophysics, New York: Springer, 1998. 283p.

Daughtry, C. S. T.; Walthall, C. L.; Kim, M. S.; Brown de Colstoun, E.; McMurtrey III, J. E. Estimating corn leaf chlorophyll concentration from leaf and canopy reflectance. Remote Sensing of Environment, St. Paul, v.74, n.2, p.229239. 2000.

Gao, Bo-Cai; Li, R. Quantitative improvement in the estimates of NDVI values from remotely sensed data by correcting thin cirrus scattering effects. Remote Sensing of Environment, St. Paul, v.74, n.3, p.494-502, 2000.

Gitelson, A. G.; Kaufman, Y. J.; Merzlyak, M. N. Use of a green channel in remote sensing of global vegetation from EOSMODIS. Remote Sensing of Environment, St. Paul, v.58, n.3, p.289-298. 1996.

Iqbal, M. An introduction to solar radiation, New York: Academic Press, Inc., 1983. 390p.

Liu, B. Y. H.; Jordan, R. C. The interrelationship and characteristic distribution of direct, diffuse and total solar radiation. Solar Energy, Gainesville, v.4, n.3, p.1-19. 1960.

Peterson, T. A.; Blackmer, T. M.; Francis, D. D.; Schepers, J. S. Using a chlorophyll meter to improve $\mathrm{N}$ management. Nebguide G93-1171A.Cooperative Extension Service, Lincoln: University of Nebraska. 1993. 6p.

Scharf, P.; Lory, J. A. Calibration of remotely sensed corn color to predict nitrogen need. In: 5th International Conference on Precision Agriculture, Madison. 2000. Proceedings... Madison: ASA-CSA-SSSA, 2000. CD Rom.

Simpson, J. J.; Jin, Z.; Stitt, J. R. Cloud shadow detection under arbitrary viewing and illumination conditions. IEEE Transactions on Geoscience and Remote Sensing, Piscataway, v.38, n.2, p.972-976. 2000.

Tumbo, D. S.; Wagner, D. G.; Heinemann, P. H. Real-world hyperspectral characteristics of corn plants under different chlorophyll levels. 2000 ASAE Annual International Meeting. ASAE Paper No. 001093. St. Joseph: ASAE. 2000. 16p. 